\title{
CASP5 wt Allele
}

National Cancer Institute

\section{Source}

National Cancer Institute. CASP5 wt Allele. NCI Thesaurus. Code C49555.

Human CASP5 wild-type allele is located within 11q22.2-q22.3 and is approximately $15 \mathrm{~kb}$ in length. This allele, which encodes caspase- 5 protein, is involved in the mediation of apoptosis. 